\title{
Physical Exercise Prevents Stress-Induced Activation of Granule Neurons and Enhances Local Inhibitory Mechanisms in the Dentate Gyrus
}

\author{
Timothy J. Schoenfeld, Pedro Rada, Pedro R. Pieruzzini, Brian Hsueh, and Elizabeth Gould \\ Department of Psychology, Neuroscience Institute, Princeton University, Princeton, New Jersey 08544
}

Physical exercise is known to reduce anxiety. The ventral hippocampus has been linked to anxiety regulation but the effects of running on this subregion of the hippocampus have been incompletely explored. Here, we investigated the effects of cold water stress on the hippocampus of sedentary and runner mice and found that while stress increases expression of the protein products of the immediate early genes c-fos and arc in new and mature granule neurons in sedentary mice, it has no such effect in runners. We further showed that running enhances local inhibitory mechanisms in the hippocampus, including increases in stress-induced activation of hippocampal interneurons, expression of vesicular GABA transporter (vGAT), and extracellular GABA release during cold water swim stress. Finally, blocking GABAA receptors in the ventral hippocampus, but not the dorsal hippocampus, with the antagonist bicuculline, reverses the anxiolytic effect of running. Together, these results suggest that running improves anxiety regulation by engaging local inhibitory mechanisms in the ventral hippocampus.

\section{Introduction}

Long-term physical exercise is anxiolytic for rodents and humans (Duman et al., 2008; Herring et al., 2010). Reduced anxiety following exercise may be the result of changes in the hippocampus, a highly plastic brain region implicated in anxiety regulation (Bannerman et al., 2004; Fanselow and Dong, 2010; Leuner and Gould, 2010). In adult rodents, running increases the number of new excitatory neurons in the dentate gyrus (van Praag et al., 1999; Olson et al., 2006; Stranahan et al., 2006; Ables et al., 2010). Running also stimulates the production of more dendritic spines, primary sites of excitatory synapses, on excitatory neurons throughout the hippocampal circuitry (Redila and Christie, 2006; Stranahan et al., 2007; Leuner and Gould, 2010).

The ventral hippocampus of rodents has been implicated in emotional processing, such as stress and anxiety regulation (Bannerman et al., 2004; Fanselow and Dong, 2010; Snyder et al., 2011). Lesions of the ventral hippocampus decrease anxiety-like behavior on a number of tasks (Bannerman et al., 2004; Fanselow and Dong, 2010). Conversely, increased activity in the ventral hippocampus correlates positively with anxious behavior (Adhikari et al., 2010, 2011). These results raise the question of how running-induced increases in the numbers of excitatory

Received Sept. 10, 2012; revised Dec. 20, 2012; accepted March 4, 2013.

Author contributions: T.S. and E.G. designed research; T.S., P.R., P.R.P., and B.H. performed research; T.S., P.R., and E.G. analyzed data; T.S. and E.G. wrote the paper.

This work was supported by a grant from the National Institute of Mental Health (MH091567 to E.G.) We thankA. Brockett, G. Kane, and M. Runkle for technical assistance.

P. Rada's and P. R. Pieruzzini's present address: Laboratory of Behavioral Physiology, School of Medicine, University of Los Andes, Mérida, Venezuela.

Correspondence should be addressed to Elizabeth Gould, Department of Psychology, Neuroscience Institute, Princeton University, Princeton, NJ 08544. E-mail: goulde@princeton.edu.

DOI:10.1523/JNEUROSCI.5352-12.2013

Copyright $@ 2013$ the authors $\quad 0270-6474 / 13 / 337770-08 \$ 15.00 / 0$ neurons and excitatory connections in the ventral hippocampus, a region that is potentially anxiogenic, can co-occur with decreased anxiety? One possibility is that the hippocampus of runners has an entirely different response to stress than the hippocampus of sedentary animals, one that involves dampening activity of excitatory neurons. A previous study showing that physical exercise alters GABAA receptor expression in the dentate gyrus (Hill et al., 2010) raises the possibility that local inhibitory mechanisms may be affected by running but no studies have yet investigated the stress response of GABAergic measures in the dentate gyrus of runners. To investigate whether running changes the activation of the hippocampus in response to an anxiety-provoking stimulus, we examined whether sedentary and runner adult male mice differ in the expression of the protein products of the immediate early genes (IEG) c-fos and arc, indirect markers of neuronal activation (Luckman et al., 1994; Guzowski et al., 2006), by new and mature granule cells in response to cold water swim stress. To examine whether running changes local inhibitory activation to a stressor, we measured stress-induced expression of immediate early genes by inhibitory interneurons, stress-induced GABA release, as well as the expression of vesicular GABA transporter (vGAT) in the hippocampus. Finally, we attempted to reverse the anxiolytic action of running by blocking GABAA receptors in the ventral hippocampus.

\section{Materials and Methods}

Adult male C57BL/6 mice (6 weeks of age) were group housed, provided food and water ad libitum, and maintained on a $12 \mathrm{~h}$ light/dark cycle. Runners had ad libitum access to an external running wheel (Lafayette Instruments). All experiments were performed in compliance with the Princeton University Institutional Animal Care and Use Committee and the NRC Guide for the Care and Use of Laboratory Animals.

Immediate early gene expression in new and mature granule cells of the dentate gyrus. To label new neurons, mice were injected intraperitoneally 
with bromodeoxyuridine (BrdU; $50 \mathrm{mg} / \mathrm{kg}$ ) daily for the first 2 weeks of 6 weeks of running or sedentary living. This BrdU injection regimen is sufficient to label a large number of new cells and to allow their differentiation into mature neurons (Snyder et al., 2009a). Because running itself has been shown to increase IEG expression in the hippocampus (Oladehin and Waters, 2001; Clark et al., 2011), we locked the running wheels $24 \mathrm{~h}$ before cold water swim to separate the effects of acute running from those of stress. To test the effects of stress on IEG activation, mice were subjected to cold water swim stress or no stress for $5 \mathrm{~min}$. Cold water swim stress was selected as a stressor because it produces a robust increase in corticosterone levels and is an ethologically relevant stressor (DeVries et al., 1997; Drazen et al., 2001; Lafrance et al., 2010). After a $30 \mathrm{~min}$ poststress interval, the mice were deeply anesthetized with sodium pentobarbital and transcardially perfused with $4 \%$ paraformaldehyde in 0.1 M phosphate buffer. The survival time of $30 \mathrm{~min}$ after stressor exposure was selected to maximize IEG expression in hippocampal excitatory neurons (Peng and Houser, 2005).

Immediate early gene expression in GABAergic interneurons of the dentate gyrus. To test whether GABAergic interneurons are differentially affected by cold water swim stress in runners compared with sedentary mice, IEG expression was examined in mice exposed to a running wheel or sedentary living for 6 weeks. After a $24 \mathrm{~h}$ break from running, mice were subjected to cold water swim stress or no stress for $5 \mathrm{~min}$ as described above. A $2 \mathrm{~h}$ poststress survival period was used for this experiment to maximize IEG expression in inhibitory neurons (Peng and Houser, 2005). After this time, mice were perfused as described above and their brains were processed for markers of inhibitory interneuronsGAD67, a global marker of GABAergic cells, or parvalbumin (PV), a marker of basket cells and chandelier cells, interneurons known to exert a profound inhibitory influence over granule cells, combined with c-fos. Previous studies (Vazdarjanova et al., 2006; Mainardi et al., 2009) as well as our preliminary data have shown that inhibitory interneurons do not express arc, so only c-fos was used for this experiment.

Extracellular GABA release in the ventral hippocampus. To test whether runners and sedentary mice differ in stress-induced release of GABA in the ventral hippocampus, chronic guide shafts were implanted in the ventral hippocampus of mice as described below before 6 weeks of running or sedentary living. Extracellular microdialysis samples were obtained (Rada et al., 2010) before, during, and after cold water swim stress at $30 \mathrm{~s}$ intervals. These samples were analyzed for GABA content using micellar electrokinetic chromatography (MEKC) (Skirzewski et al., 2011) as described below.

Anxiety-like behavior. To determine whether blockade of GABAA receptors, an abundant GABA receptor in the hippocampus (Atack, 2011), can eliminate the anxiolytic action of running, runner and sedentary mice were subjected to implantation of cannulae in the ventral hippocampus after 3 weeks of running. After 1 week of recovery from surgery, the GABAA receptor antagonist bicuculline or vehicle was infused directly into the ventral hippocampus. Ten minutes following injection, mice were tested on the elevated plus maze as described below (Cornélio and Nunes-de-Souza, 2007; Rezvanfard et al., 2009). A shorter period of running was used for this study because 3 weeks of running was sufficient to produce an anxiolytic response comparable in magnitude to that of 6 weeks of running. For comparison purposes, a similar experiment was conducted involving infusions of bicuculline or vehicle into the dorsal hippocampus after 3 weeks of running. It should be noted that, unlike the experiments included in this report, our pilot studies included bicuculline infusions into the hippocampus of sedentary mice. Many of the sedentary mice in our pilot studies had obvious seizures after bicuculline infusion while none of the runner mice showed this effect. Because we could not assess anxiety-like behavior in mice with seizures, we did not include bicuculline infused sedentary groups in our subsequent studies. Bicuculline has been shown to induce seizures (Freund et al., 1987) in control (sedentary) mice and our data raise the possibility that running increases the seizure threshold in the hippocampus.

Behavioral manipulations and measures. For cold water swim stress, mice were placed in rectangular containers $(20 \times 20 \times 20 \mathrm{~cm})$ filled with ice water $\left(\sim 5^{\circ} \mathrm{C}\right)$ for $5 \mathrm{~min}$. After $5 \mathrm{~min}$, mice were taken out of the cold water, dried with paper towel, and returned to their home cage until perfusion.

For anxiety testing at 3 and 6 weeks after running, the elevated plusmaze, a common test of anxiety-like behavior in rodents, was used (Lister, 1987; Walf and Frye, 2007). Mice were placed on an elevated (50 $\mathrm{cm})$ plus-shaped track. Two of the arms had high walls $(30 \mathrm{~cm})$ while the other two arms and central intersection were open. All arms were $50 \mathrm{~cm}$ in length, dimly lit by reflected light. Exploratory behavior was measured for $5 \mathrm{~min}$ and analyzed. Number of entries into the open and closed arms, and time spent in the open arms were measured for each mouse. Because the open arms are more exposed to the light and open air, more time spent in the open arms is considered a measure of reduced anxiety (Heldt et al., 2012; O'Leary et al., 2013; Pritchard et al., 2013; Zheng and Rinaman, 2013). Total entries into both closed and open arms are considered a measure of locomotion (File and Aranko, 1988; Clénet et al., 2006; Hayase, 2013).

Craniotomy. Mice were anesthetized with ketamine/xylazine, shaved and placed in a stereotaxic instrument (David Kopf Instruments). Cannulae were implanted using the following coordinates: for ventral hippocampus, $3.16 \mathrm{~mm}$ posterior from bregma, $\pm 3.0 \mathrm{~mm}$ lateral to midline, and 4.2 ventral from the dura; for dorsal hippocampus, $2.0 \mathrm{~mm}$ posterior from bregma, $\pm 2.0 \mathrm{~mm}$ lateral to midline, and 1.5 ventral from the dura (Adhikari et al., 2010). Bilateral cannulae were inserted at depths of $0.5 \mathrm{~mm}$ ventral to dura in an effort to prevent excessive damage and injector needles were lowered the remaining depth during microinfusion. Surgical screws were inserted in the skull around the guide cannulae, and the cannulae (26 ga, $5 \mathrm{~mm}$ pedestal, $3 \mathrm{~mm}$ tubing length; Plastics One) were lowered into place. Dental acrylic was applied to stabilize and seal the wound and dummy caps (Plastics One) were used to block cannulae from clogging.

Drug preparation and microinfusion. Bicuculline (National Cancer Institute; \#32192/2), a GABAA receptor antagonist (Curtis et al., 1970), was dissolved in $0.1 \mathrm{M} \mathrm{HCl}$ :saline, and titrated with $0.1 \mathrm{M} \mathrm{NaOH}$ :saline until a $\mathrm{pH}$ of 5.6 was achieved (de Feo et al., 1985), then diluted with saline until the concentration was $1 \mathrm{mg} / \mathrm{ml}$. Mice were manually restrained and vehicle or bicuculline was injected using a Hamilton syringe through guide cannulae with internal injectors (33 ga, Plastics One) at a rate of 0.5 $\mu \mathrm{l} / \mathrm{min}$ for $1 \mathrm{~min}$ for a total volume of $1 \mu \mathrm{l}$ per brain. After the experiment was over, mice were perfused and cannulae placement was verified.

Microdialysis. Mice were anesthetized and a guide shaft was implanted aimed at the ventral hippocampus (coordinates: $3.16 \mathrm{~mm}$ posterior from bregma, $3.0 \mathrm{~mm}$ lateral to midline, and $4.2 \mathrm{~mm}$ ventral from the dura). Concentric microdialysis probes were constructed in the laboratory as previously described (Rada et al., 2010). Mice had probes lowered through the guide shaft into the ventral hippocampus and fixed in place $14 \mathrm{~h}$ before experimentation. Probes were perfused with a modified Ringer's solution ( $136.0 \mathrm{~mm} \mathrm{NaCL}, 3.7 \mathrm{~mm} \mathrm{KCl}, 1.2 \mathrm{~mm} \mathrm{CaCl}_{2}, 1.0 \mathrm{~mm}$ $\mathrm{MgCl}_{2}$, and $10.0 \mathrm{~mm} \mathrm{NaHCO}$ at $\mathrm{pH}$ 7.4) at a flow rate of $1 \mu \mathrm{l} / \mathrm{min}$. Each sample was collected during $30 \mathrm{~s}$, taking 3 samples before the stressor (baseline) followed by 3 samples throughout the stressor, and 5 samples after the end of stressor. Microdialysis samples were analyzed using MEKC (Rada et al., 1999; Skirzewski et al., 2011). Samples were prepared by mixing a $66 \mu \mathrm{m}$ solution of fluorescein (Sigma) in $20 \mathrm{~mm}$ carbonate buffer at $\mathrm{pH} 9.4$ with a $2.5 \mathrm{~mm}$ solution of fluorescein isothiocyanate isomer-I (FITC) (Sigma) in acetone in a 1:1 (v/v) ratio. The samples reacted overnight $(16 \mathrm{~h})$ in dark at room temperature and in a water saturated chamber to avoid evaporation. Ten microliters of derivatizing solution were mixed with $1 \mathrm{ml}$ of a $9.7 \mathrm{~mm}$ GABA solution to react overnight. We used a Meridialysis capillary zone electrophoresis system (Model R2D2, Mérida) equipped with an argon laser $(20 \mathrm{~mW})(\mathrm{Om}-$ nichrom) tuned to $488 \mathrm{~nm}$. A fiber optic conducted the laser beam onto a dichroic mirror centered at $510 \mathrm{~nm}$ and focused on the window of a capillary (Polymicro Technologies) by a 0.85 -numeric aperture objective. The window was made by burning out the polyimide coating at 35 $\mathrm{cm}$ from the anodic end of a $45 \mathrm{~cm}$ long capillary, with a $26 \mu \mathrm{m}$ internal diameter and 358 of outside diameter, fused-silica capillary. The fluorescence was captured through the objective and focused on a multialkali photomultiplier tube.

The running buffer was a $40 \mathrm{~mm}$ borate buffer with $20 \mathrm{~mm}$ SDS. The sample was loaded at the anodic end by a negative pressure (12 p.s.i. for 
$0.5 \mathrm{~s})$ applied at the cathodic end of the capillary. Electrophoretic separation was obtained by applying $28 \mathrm{kV}$ between the anode and cathode for $25 \mathrm{~min}$. Before each run, the capillary was rinsed with $1 \mathrm{~m} \mathrm{NaOH}$ for $5 \mathrm{~min}$ followed by water for $5 \mathrm{~min}$ and running buffer for $5 \mathrm{~min}$. Data were normalized as the percentage of baseline. After the experiment was over, mice were perfused and the brains examined for probe placement.

Immunohistochemistry. Coronal sections (1:8) were cut at $40 \mu \mathrm{m}$ throughout the entire hippocampus with a Vibratome. For BrdU peroxidase staining, sections were mounted onto slides and allowed to dry overnight. Sections were pretreated by heating in $0.1 \mathrm{M}$ citric acid, $\mathrm{pH}$ 6.0. Slides were rinsed with PBS, digested in trypsin for $10 \mathrm{~min}$, rinsed, denatured in $2 \mathrm{~N} \mathrm{HCl}$ :PBS for $30 \mathrm{~min}$, rinsed, incubated with mouse antiBrdU antibody (1:250 with 10\% Tween 20; BD Bioscience), and stored at $4^{\circ} \mathrm{C}$. The following day, slides were rinsed with PBS, incubated in biotinylated horse anti-mouse (1:200; Vector) for $60 \mathrm{~min}$, rinsed, incubated in avidin-biotin complex for $60 \mathrm{~min}$, rinsed, and reacted with diaminobenzidine (DAB) for $6 \mathrm{~min}$.

For c-fos and arc protein peroxidase immunostaining, free-floating sections were rinsed in PBS, incubated in $0.3 \% \mathrm{H}_{2} \mathrm{O}_{2}$ in absolute methanol for $20 \mathrm{~min}$ to block endogenous peroxidase activity, rinsed, incubated in 3\% normal goat serum (Vector) to prevent nonspecific binding, transferred directly into rabbit anti-c-fos (1:1000; Santa Cruz Biotechnology) or rabbit anti-arc (1:1000; Synaptic Systems) antibody and stored at $4^{\circ} \mathrm{C}$. Two days later, tissue was rinsed, incubated in biotinylated goat anti-rabbit (1:200; Vector) for $60 \mathrm{~min}$, rinsed, incubated in avidinbiotin complex for $60 \mathrm{~min}$, rinsed, and reacted with $\mathrm{DAB}$ for $10 \mathrm{~min}$. Tissue was mounted to suprafrost slides and allowed to dry for a minimum of $2 \mathrm{~h}$. All peroxidase tissue was counterstained with $0.5 \%$ cresyl violet and coverslipped under Permount (Fisher Scientific).

For combined BrdU-IEG immunofluorescence, free-floating sections were rinsed in $0.1 \mathrm{M} \mathrm{TBS}, \mathrm{pH} 7.5$, denatured in $2 \mathrm{~N} \mathrm{HCl}$ :TBS for $30 \mathrm{~min}$, rinsed, and incubated with rat anti-BrdU (1:200 with $0.5 \%$ Tween 20 ; Accurate Chemical) plus rabbit anti-c-fos (1:200; Santa Cruz Biotechnology) or rabbit anti-arc (1:1000; Synaptic Systems) and stored at $4^{\circ} \mathrm{C}$. Three days later, sections were rinsed, incubated in biotinylated goat anti-rat (1:250; Millipore Bioscience Research Reagents) for $90 \mathrm{~min}$, rinsed, and incubated in streptavidin-conjugated Alexa 568 (1:1000; Invitrogen) to visualize BrdU and goat anti-rabbit Alexa 488 (1:500; Invitrogen) to visualize c-fos and arc, in the dark for $60 \mathrm{~min}$. Sections were rinsed and mounted onto suprafrost slides, and coverslipped using glycerol in TBS $(3: 1)$. Slides were kept in dark at $4^{\circ} \mathrm{C}$ until microscopic analyses.

For interneuron-IEG immunofluorescence, free-floating sections were rinsed in $0.1 \mathrm{~m}$ TBS, $\mathrm{pH} 7.5$, and incubated with mouse anti-PV (1:1000, Sigma) or mouse anti-GAD67 (1:2000; Millipore) plus rabbit anti-c-fos (1:200 with 0.5\% Tween 20; Santa Cruz Biotechnology), and stored at $4^{\circ} \mathrm{C}$. Arc was not used because inhibitory interneurons in the hippocampus do not express this immediate early gene (Vazdarjanova et al., 2006; Mainardi et al., 2009). Two days later, sections were rinsed, incubated in goat anti-mouse Alexa 568 (1:500; Invitrogen) to visualize interneurons and goat anti-rabbit Alexa 488 (1:500; Invitrogen) to visualize c-fos, in the dark for $60 \mathrm{~min}$. Sections were rinsed and mounted onto suprafrost slides, and coverslipped using glycerol in TBS $(3: 1)$. Slides were kept in dark at $4^{\circ} \mathrm{C}$ until microscopic analyses.

For vGAT or vGLUT immunofluorescence, free-floating sections were rinsed in $0.1 \mathrm{M}$ TBS, pH 7.5, incubated in 3\% normal goat serum (Vector) to prevent nonspecific binding, and incubated with guinea pig antivGLUT1 (1:5000; Millipore) or rabbit anti-vGAT (1:500, Synaptic Systems) with $0.5 \%$ Tween 20 and stored at $4^{\circ} \mathrm{C}$. Three (vGLUT1) or one day(s) (vGAT) later, sections were rinsed, incubated in goat anti-guinea pig Alexa 488 (1:500; Invitrogen) to visualize vGLUT1 or goat anti-rabbit Alexa 488 (1:500; Invitrogen) to visualize vGAT, in the dark for $120 \mathrm{~min}$. Sections were rinsed and mounted onto suprafrost slides, and coverslipped using glycerol in TBS (3:1). Slides were kept in dark at $4^{\circ} \mathrm{C}$ until microscopic analyses.

Microscopic data analysis. Slides were coded until completion of the data analysis. Sections through the hippocampus were designated dorsal or ventral before analyzing (Banasr et al., 2006). Other hippocampal regions (CA1 and CA3) were designated using the Allen Brain Atlas (http://mouse.brain-map.org/). For the dentate gyrus, estimates of the total number of BrdU, c-fos, and arc-labeled cells in the granule cell layer were determined using peroxidase stained tissue. For CA1 and CA3 regions, estimates of the total number of c-fos and arc-labeled cells were determined throughout the pyramidal cell layer. Labeled cells were counted in one hemisphere and counts were multiplied by 16 to estimate the number of labeled cells in the entire area.

All BrdU+, PV +, or GAD67+ cells on every eighth section through the entire dentate gyrus, including the granule cell layer, hilus, and molecular layer, were examined for colabeling with c-fos or arc with a Zeiss Axiovert confocal laser-scanning microscope (510 LSM; lasers, argon 458/488, and HeNe 543). Each possible double-labeled cell was scanned by obtaining optical stacks of $1-\mu \mathrm{m}$-thick sections and analyzed. To verify double-labeling, cells were examined in orthogonal planes. For optical intensity measurements of vGAT and vGLUT, confocal analysis was performed as previously described (Singer et al., 2011). Ten representative 1 $\mu \mathrm{m}$ optical slices from the granule cell layer and molecular layer of the dorsal and ventral dentate gyrus were scanned and measured for optical intensity from each brain. Raw intensity values were divided by average intensity measurements from the fornix of each brain to control for variability in staining intensity between brains.

Statistical analysis. Depending on the number of groups in an experiment, unpaired Student's $t$ tests, one or two-way ANOVA followed by Fisher LSD post hoc tests were used. Graphs display mean + SEM.

\section{Results}

Running increases the number of new neurons in the dentate gyrus and decreases anxiety-like behavior

Consistent with previous studies (van Praag et al., 1999; Stranahan et al., 2006), we found that long-term running (6 weeks) increased the number of new neurons throughout the dentate gyrus $\left(F_{(1.29)}=\right.$ $69.61, p=0.0000001$ ) (Fig. 1 A, B), but not in the subventricular zone (mean \pm SEM-Sedentary (Sed): $1703.37 \pm 137.98$; Runner (Run): $1576.67 \pm 81.33 ; F_{(1,32)}=0.72, p=0.401$ ). Also consistent with previous studies showing that running reduces anxiety without affecting overall locomotion (Duman et al., 2008; Salam et al., 2009), long-term running (6 weeks) decreased the amount of time spent in the open arms (mean \pm SEM-Sed: $73.11 \pm 8.36$; Run: $\left.112.30 \pm 7.69 ; F_{(1,17)}=11.94, p=0.004\right)$ without affecting the number of total arm entries (open + closed) (mean \pm SEM-Sed: $9.78 \pm 0.81$; Run: $9.20 \pm 0.53$; $\left.F_{(1,17)}=0.37, p=0.552\right)$.

\section{Running prevents stress-induced activation of new neurons in the ventral dentate gyrus}

In sedentary mice, exposure to cold water swim stress increased the percentage of BrdU labeled cells that stained for either c-fos or arc in the ventral dentate gyrus. No such stress effect was observed in runners (significant interactions: c-fos: $F_{(1,29)}=11.48$, $p=0.002$; arc: $F_{(1,29)}=7.61, p=0.018$ ) (Fig. $1 C, D$ ). Neither sedentary mice nor runners exhibited an increase in the percentage of BrdU labeled cells that expressed either immediate early gene in the dorsal dentate gyrus $(p>0.05)$.

\section{Running prevents stress-induced activation of hippocampal granule cells and pyramidal cells}

The effects for the overall granule cell population in the ventral dentate gyrus were similar to those observed for BrdU labeled granule cells. Exposure to cold water swim stress increased c-fos and arc expression overall in the granule cell layer of the ventral dentate gyrus of sedentary mice, but this stress-induced neuronal activation was prevented in runners (c-fos ventral dentate gyrus: $F_{(1,29)}=4.80, p=0.04$; arc ventral dentate gyrus: $F_{(1,29)}=7.80, p=$ 0.009 ) (Fig. $1 E, F$ ). Likewise, in the CA3 and CA1 fields of the ventral hippocampus, stress increased c-fos and arc expression in sedentary 


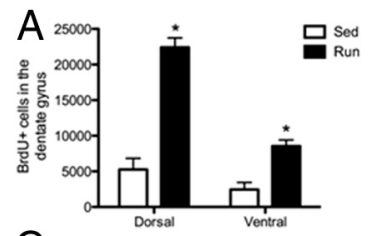

C
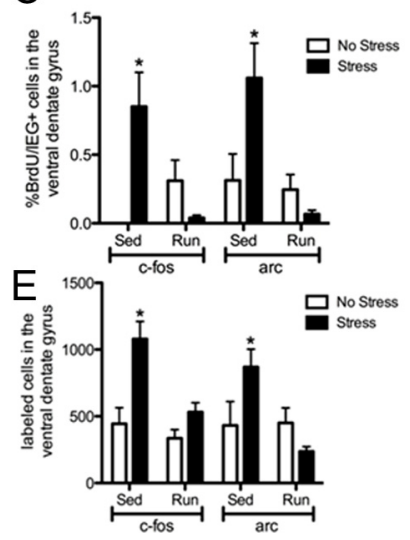

B

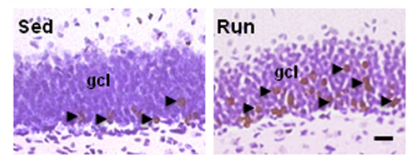

D

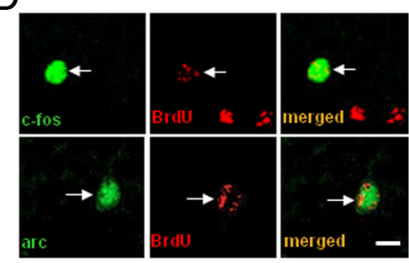

$\mathrm{F}$

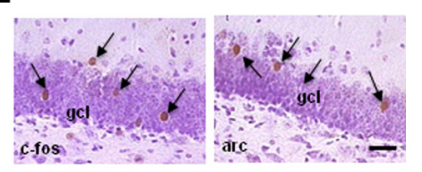

Figure 1. Running increases the number of new granule neurons in the dentate gyrus but prevents stress-induced increases in IEG expression in new and mature granule cells. These mice ran or were sedentary for 6 weeks, received BrdU injections from days 2-15 of the experiment, and were perfused $30 \mathrm{~min}$ after cold water swim stress or no stress. $\boldsymbol{A}$, Long-term running increases the number of BrdU-labeled cells in both dorsal and ventral dentate gyrus of adult mice. $\boldsymbol{B}$, Photomicrographs of BrdU-labeled cells (arrowheads) in the dentate gyrus that are more numerous in runner than sedentary mice. C, Cold water swim stress increases the percentage of new neurons (BrdU-labeled cells) that express c-fos or arc in sedentary, but not runner, mice. D, Confocal images of cells (arrows) labeled with BrdU (red) and c-fos (green) or arc (green). $\boldsymbol{E}$, Cold water swim stress increases the number of granule cells that express c-fos or arc in sedentary but not runner mice. $\boldsymbol{F}$, Photomicrographs of c-fos (left) and arc (right) positive cells in the dentate gyrus. Error bars represent SEM. * $p<0.05$ compared with Sed for $\boldsymbol{A}$; compared with no stress Sed for $\boldsymbol{C}, \boldsymbol{E}$. Scale bars: in $\boldsymbol{B}, \boldsymbol{F}, 20 \mu \mathrm{m}$; in $\boldsymbol{D}, 10 \mu \mathrm{m}$.

mice (mean \pm SEM-CA3 c-fos: no stress: $424.09 \pm 128.25$; stress: 3918.22 \pm 762.38; arc: no stress: $1395.2 \pm 437.22$; stress: $4064.00 \pm$ 789.57; CA1 c-fos: no stress: $340.95 \pm 116.18$; stress: $3427.56 \pm$ 479.21; arc: no stress: $329.6 \pm 146.52$; stress: $1384.89 \pm 244.46)$ but not in runners (CA3 c-fos: no stress: $1523.28 \pm 285.19$; stress: $2254.40 \pm 662.13$; arc no stress: $2571.2 \pm 645.11$; stress: $2747.2 \pm$ 618.47; CA1: c-fos no stress: $996.85 \pm 237.86$; stress: $1729.61 \pm$ 321.07 arc: no stress: $900.8 \pm 159.93$; stress: $1088.45 \pm 314.62$; significant interactions: $c$-fos ventral CA3: $F_{(1,29)}=4.44, p=0.04$; $c$-fos ventral CA1: $F_{(1,29)}=9.23, p=0.005$; simple effects: sedentary arc ventral CA3: $F_{(1,30)}=5.69, p=0.023$; sedentary arc ventral CA1: $\left.F_{(1,30)}=6.74, p=0.014\right)$.

\section{Running enhances stress-induced activation of inhibitory} interneurons and GABA release

As previously reported, no cells labeled for the interneuron markers GAD67 or PV were colabeled with arc (Vazdarjanova et al., 2006; Mainardi et al., 2009). Quantitative analysis of cells double labeled for interneuron markers and c-fos revealed that a higher proportion of GAD67- or PV-interneurons expressing c-fos were observed in the ventral dentate gyrus of runners in response to cold water swim stress compared with sedentary mice. This difference was observed for GAD67 + cells throughout the dentate gyrus (granule cell layer, hilus, and molecular layer) and for PV+ cells in the granule cell layer and hilus (GAD67: granule cell layer: $F_{(1,18)}=5.91, p=0.026$; hilus: $F_{(1,18)}=5.98, p=0.025$; molecular layer: $F_{(1,18)}=7.29, p=0.015$; PV: granule cell layer:

A
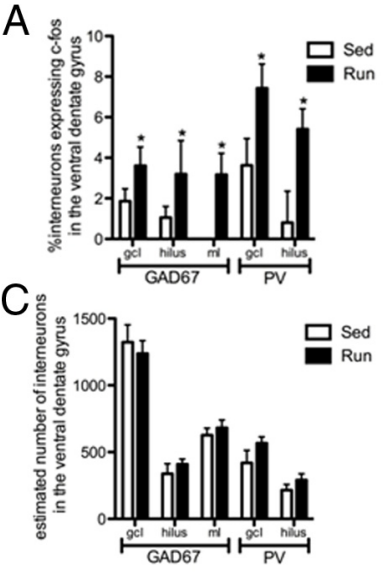

D
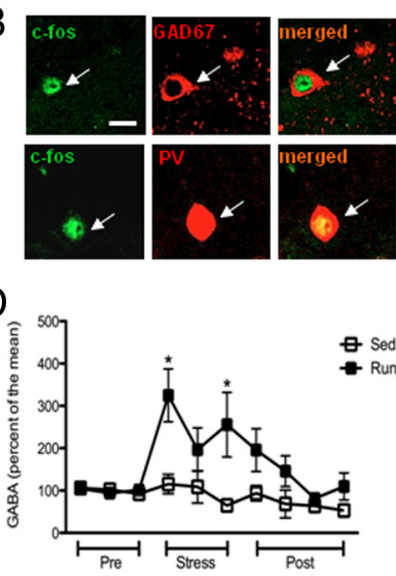

E

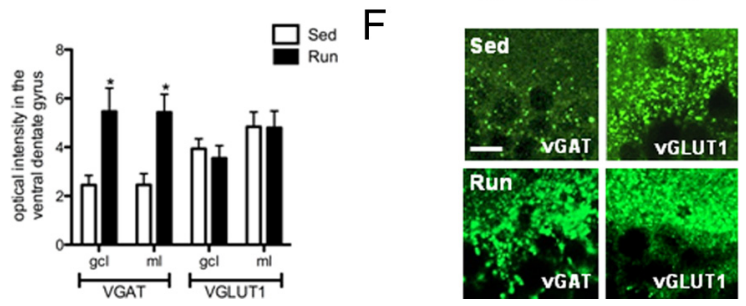

Figure 2. Runners exhibit increases in hippocampal GABAergic measures in response to cold water swim stress. These mice ran or were sedentary for 6 weeks, were exposed to cold water swim, and were either perfused $2 \mathrm{~h}$ later for immunolabeling or subjected to in vivo microdialysis for measurement of extracellular GABA. $\boldsymbol{A}$, Following cold water swim stress, runners exhibit a greater percentage of GABAergic interneurons (GAD67 or PV positive) that express $\boldsymbol{C}-\mathrm{fos}$ in the ventral dentate gyrus than sedentary mice. $\boldsymbol{B}$, Confocal images of c-fos (green) colabeled with GAD67 (red, top) and PV (red, bottom). C, No differences were detected in the number of GAD67 + or PV + cells in the dentate gyrus between runners and sedentary mice. $\boldsymbol{D}$, Cold water swim stress produces greater extracellular GABA in the ventral dentate gyrus of runners compared with sedentary mice. $\boldsymbol{E}$, Runners exhibit greater expression of vGAT, but not VGLUT1, throughout the dentate gyrus compared with sedentary mice. $\boldsymbol{F}$, Confocal images of VGAT and VGLUT1 expression in the dentate gyrus of stressed sedentary and runner mice. Error bars represent SEM. ${ }^{*} p<0.05$. ml, Molecular layer. Scale bars: in $\boldsymbol{B}, 10 \mu \mathrm{m}$; in $\boldsymbol{F}, 20 \mu \mathrm{m}$.

$F_{(1,18)}=4.56, p=0.047$; hilus: $F_{(1,18)}=6.941, p=0.017$ ) (Fig. $2 A, B)$. There were no significant increases in the proportion of c-fos + cells that were PV + and GAD67 + interneurons in the granule cell layer $(\mathrm{gcl})$ or hilus between runners and sedentary mice in the dorsal dentate gyrus $(p>0.05)$. There were no changes in the number of PV + or GAD67+ cells in any location of the dentate gyrus $(p>0.05)$ (Fig. $2 C$ ).

Cold water swim stress led to an increase in extracellular GABA in the ventral hippocampus of runners compared with sedentary mice (significant interaction: $F_{(9,63)}=4.34, p=$ 0.0002 ) (Fig. 2D). Extracellular GABA release was higher in runners at the onset and during stress compared with sedentary mice (onset: $F_{(1,7)}=10.17, p=0.015$; during: $F_{(1,7)}=6.07, p=0.043$ ). After stress, extracellular GABA returned to baseline in runners.

Runners had a greater intensity of vGAT staining in the ventral dentate gyrus compared with sedentary mice regardless of whether they were exposed to cold water stress (unstressed: granule cell layer: $F_{(1,16)}=15.17, p=0.001$; molecular layer: $F_{(1,16)}=$ $10.79, p=0.005$; stressed: granule cell layer: $F_{(1,18)}=8.41, p=$ 0.01; molecular layer: $F_{(1,18)}=11.74, p=0.003$ ) (Fig. $2 E, F$ ). By contrast, long-term running did not affect expression of vGLUT1, a vesicular glutamate transporter, throughout the dentate gyrus $(p>0.05)$ (Fig. $2 E, F)$. 
Decreases in anxiety-like behavior in runners are prevented by GABAA receptor blockade in the ventral, but not dorsal, hippocampus

Three weeks of running produced an anxiolytic response, i.e., it increased the amount of time spent in the open arms, that was similar to 6 weeks of running on the elevated plus maze-this effect was blocked by infusion of the GABAA receptor antagonist bicuculline into the ventral hippocampus (main effect, $F_{(2,22)}=$ $15.50, p=0.00006$ ) (Fig. 3A). GABAA receptor antagonist treatment did not alter the combined number of entries into open and closed arms suggesting that there was no change in overall locomotion $\left(F_{(2,22)}=0.75, p=0.484\right)$ (Fig. 3B). By contrast, infusion of bicuculline or vehicle into the dorsal hippocampus did not alter the anxiolytic actions of running (main effect, $F_{(2,19)}=3.702, p=0.044$, running and running + dorsal hippocampal bicuculline were not significantly different, $p>0.05$ ) (Fig. 3C) nor did it affect the overall number of entries into the open and closed arms $\left(F_{(2,19)}=0.08, p=\right.$ 0.9247) (Fig. 3D). It should be noted that although running increased the amount of time spent in the open arms significantly, it had no statistically significant effect on the number of entries into open arms $(p>0.05)$. Although both the amount of time spent in the open arms and the number of open arm entries are viewed as measures of anxiety-like behavior on the elevated plus maze, time spent in the open arms has been shown to be more sensitive to experimental manipulations in several previous studies and to more often correlate positively with other measures of anxiety than number of open arm entries (Motevasseli et al., 2010; Heldt et al., 2012; O'Leary et al., 2013; Pritchard et al., 2013; Zheng and Rinaman, 2013).

\section{Discussion}

Our findings indicate that despite the presence of more new neurons in runners, a smaller proportion of these cells were activated in the ventral dentate gyrus in response to cold water swim stress compared with sedentary mice. This prevention cannot be explained by a general blunting effect on the activation of new neurons by exercise, because studies have shown that runners have increased seizure-induced expression of immediate early genes in new neurons compared with controls (Snyder et al., 2009 b). Previous studies have shown that small numbers of new neurons in the dentate gyrus are activated by engaging in behaviors that depend on the hippocampus, including spatial navigation and learning (Ramirez-Amaya et al., 2006; Kee et al., 2007; Tashiro et al., 2007; Snyder et al., 2009c; Epp et al., 2011; Snyder et al., 2012). Other experiences that generally activate the hippocampus, such as exercise and seizures, have been shown to activate new neurons as well (Jessberger and Kempermann, 2003; Snyder et al., 2009a; Clark et al., 2011). Our findings add stress to the growing list of experiences that can activate new neurons in the dentate gyrus. As with new neurons, the larger granule cell population (which includes both mature and immature neurons
B
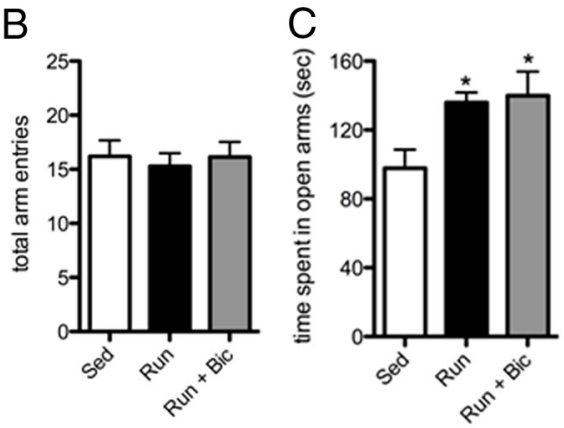

D
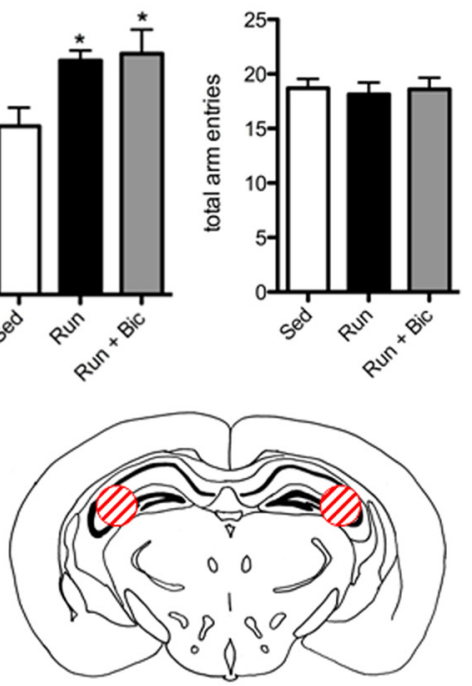

Figure 3. Blockade of GABAA receptors in the ventral hippocampus prevents the anxiolytic response of long-term running. bicuculline or vehicle into the ventral or dorsal hippocampus before testing on the elevated plus maze. $A$, Bicuculline in the ventral . ${ }^{*} p<0.05$ compared with sedentary mice. Error bars represent SEM. Run + Bic, Runner mice with bicuculline infusions. Atlas sections show representative infusion areas in the ventral hippocampus (left) and dorsal hippocampus (right).

with a preponderance of the former) is also activated by cold water swim stress.

In our experiments, the cold water stress-induced activation of the overall granule cell population did not occur in runners, suggesting that the effect is not specific to new cells. Similar findings were obtained in other excitatory neuron populations of the hippocampus-CA1 and CA3 pyramidal neurons also showed increased cold water swim stress-induced activation, but only in sedentary mice. The extent to which these responses can be generalized to other stressors remains unknown but it is relevant that multiple stressors, in addition to cold water swim, have been shown to activate mature granule cells (Sharp et al., 1991; Katano et al., 1997; Chandramohan et al., 2007, 2008), The significantly diminished stress-induced activation of new and mature excitatory neurons in the ventral hippocampus of runners suggests that reorganization of this structure may also involve populations of neurons that serve to dampen excitatory responses.

Parvalbumin-containing interneurons in the dentate gyrus form axo-somatic and axo-axonic synapses on granule cells (Houser, 2007) where they produce strong direct inhibition of granule cells (Blasco-Ibáñez et al., 2000). A single parvalbumin interneuron has been estimated to make over 11,000 synapses onto $\sim 2000$ granule neurons (Sik et al., 1997). Thus, even small numbers of parvalbumin interneurons have the potential to strongly inhibit a large population of dentate gyrus granule cells. We found that stressed runners have a higher proportion of parvalbumin-containing interneurons that express c-fos in the ventral dentate gyrus than stressed controls, with no change in the overall number of parvalbumin-containing interneurons, suggesting that these interneurons are activated in greater numbers during stress in runners. Because parvalbumin-containing interneurons are just a subpopulation of interneurons in the mouse dentate gyrus (Jinno and Kosaka, 2002), GAD67 was used 
as a global marker of interneurons in the dentate gyrus. We also found that stressed runners had a higher proportion of GAD67containing interneurons that express $\mathrm{c}$-fos in the ventral dentate gyrus, with no change in the overall number of these cells, suggesting that running may affect inhibitory interneurons in addition to those that contain parvalbumin in the ventral dentate gyrus. Increased stress-induced activation of dentate gyrus interneurons in runners may explain our observation that runners do not show a stress-induced increase in granule neuron activation.

Among the inhibitory interneuron subtypes, other than those that express PV, in the dentate gyrus are those that express vasoactive intestinal peptide (VIP) and somatostatin (SS) (Houser, 2007; Spruston and McBain, 2007) as well as the ivy/neurogliaform cells (Armstrong et al., 2011; Markwardt et al., 2011). Since VIP- and SS-containing cells are known to inhibit granule cells (Hajos et al., 1996; Tallent, 2007), they are possible additional candidates for involvement in the altered stress effects we observed in the current study. Ivy/neurogliaform cells, however, are unlikely to play such a role because they innervate immature granule cells where they produce excitatory responses as well as interneurons which inhibit granule cells (Armstrong et al., 2011; Markwardt et al., 2011). Thus, if this population showed increased activation in response to stress in runners, it would most likely produce activation of both the immature granule cells, through direct depolarization, and mature granule cells, through disinhibition (Markwardt et al., 2011). This is contrary to the pattern of results we observed. Clearly, identifying interneuron subtypes in addition to those containing PV, which are involved in mediating stress-induced inhibition of granule cells in runners, will require additional investigation, as will determining the influence of individual interneuron subtypes on running-induced changes in hippocampal function, such as anxiety regulation.

It is interesting to note that GABAergic interneurons, as well as the neuropeptides they release, have been implicated in the process of adult neurogenesis (Ge et al., 2007; Zaben et al., 2009; Song et al., 2012). These findings raise the possibility that running-induced changes in cell proliferation, neuronal differentiation, and cell survival (van Praag et al., 1999; Stranahan et al., 2006; Snyder et al., 2009) are also mediated by inhibitory interneurons. Together, these findings suggest that running may reorganize the dentate gyrus by first influencing GABAergic signaling, which in turn alters the production of new neurons and their integration into the existing circuitry.

We also found further evidence that runners have augmented inhibitory signaling by increased expression of vGAT, the presynaptic vesicular transporter of GABA, in the ventral dentate gyrus. This is not simply an effect of acute stress, as the increase in runners is apparent in nonstressed mice as well. vGAT levels have been shown to correlate with GABA release in the hippocampus during seizures (Kang et al., 2003). By contrast, there was no effect of running on vGLUT1, the presynaptic transporter of glutamate, suggesting that running does not change at least one measure of glutamatergic transmission in the dentate gyrus, but instead may alter excitatory signaling through changes in GABAergic transmission. In addition to elevated vGAT levels and increased stress-induced c-fos expression in inhibitory interneurons in runners, our results further showed that runners exhibit a greater release of GABA in the ventral hippocampus during stress than sedentary mice. Together with our other findings regarding GABAergic indices in runners, increased GABA release during stress in runners may explain the prevention of a stress-induced increase in activation of excitatory neurons in the ventral hippocampus.

Our results further suggest that the anxiolytic actions of running were reversed by injections of the GABAA receptor antagonist bicuculline directly into the ventral, but not dorsal, hippocampus. Previous studies have shown that injections of bicuculline into the ventral hippocampus increase anxiety-like behavior in controls as well as reverse the anxiolytic action of GABAA receptor agonists (Rezvanfard et al., 2009). Thus, even though we were not able to confirm this given the high incidence of bicuculline-induced seizures in our sedentary mice (see Materials and Methods), we cannot determine with certainty that we have not merely manipulated receptors that are not specific to the running effect, but that would always be capable of modulating anxious behavior. Our data are, however, consistent with the possibility that increased GABAergic signaling in runners may not only prevent stress-induced activation of excitatory neurons in the hippocampus but may also underlie the anxiolytic actions of running.

It should be noted that while many studies have shown that running reduces anxiety (Duman et al., 2008; Salam et al., 2009; Trejo et al., 2008, present report) in mice, some recent studies have shown that running can increase anxiety (Fuss et al., 2010a,b). These differences may be due to housing conditionsthe mice in the studies where running increased anxiety were housed individually while those in the present study were housed in groups. Some evidence suggests that under conditions of running increasing anxiety, new neurons contribute to this effect (Fuss et al., 2010b). These findings raise the possibility that group housing may be necessary for the anxiolytic effects of running by facilitating reorganization that leads to an enhanced GABAergic response to stress.

Our results resolve the seemingly contradictory findings that running can decrease anxiety while increasing the number of new excitatory neurons and excitatory connections in the ventral hippocampus, a potentially anxiogenic region (Adhikari et al., 2010, 2011; Fanselow and Dong, 2010). By increasing GABAergic inhibition in the hippocampus in response to stress, running may serve to calm excitatory circuitry that might otherwise produce an overly anxious state. These findings suggest that the hippocampus of runners may be fine-tuned to respond to different environments optimally (Glasper et al., 2012). That is, socially housed runners may activate their greater numbers of new neurons to enhance cognition under low stress conditions and silence these cells through local GABAergic mechanisms to reduce anxiety under high stress conditions. Whether new neurons play some role in dampening stress responses in runners or whether their silence signals no involvement under high stress conditions remains to be determined.

\section{References}

Ables JL, Decarolis NA, Johnson MA, Rivera PD, Gao Z, Cooper DC, Radtke F, Hsieh J, Eisch AJ (2010) Notch1 is required for maintenance of the reservoir of adult hippocampal stem cells. J Neurosci 30:10484-10492. CrossRef Medline

Adhikari A, Topiwala MA, Gordon JA (2010) Synchronized activity between the ventral hippocampus and the medial prefrontal cortex during anxiety. Neuron 65:257-269. CrossRef Medline

Adhikari A, Topiwala MA, Gordon JA (2011) Single units in the medial prefrontal cortex with anxiety-related firing patterns are preferentially influenced by ventral hippocampal activity. Neuron 71:898-910. CrossRef Medline

Armstrong C, Szabadics J, Tamás G, Soltesz I (2011) Neurogliaform cells in the molecular layer of the dentate gyrus as feed-forward $\gamma$-aminobutyric 
acidergic modulators of entorhinal-hippocampal interplay. J Comp Neurol 519:1476-1491. CrossRef Medline

Atack JR (2011) GABAA receptor subtype-selective modulators. II. $\alpha 5$ selective inverse agonists for cognition enhancement. Curr Top Med Chem 11:1203-1214. CrossRef Medline

Banasr M, Soumier A, Hery M, Mocaër E, Daszuta A (2006) Agomelatine, a new antidepressant, induces regional changes in hippocampal neurogenesis. Biol Psychiatry 59:1087-1096. CrossRef Medline

Bannerman DM, Rawlins JN, McHugh SB, Deacon RM, Yee BK, Bast T, Zhang WN, Pothuizen HH, Feldon J (2004) Regional dissociations within the hippocampus-memory and anxiety. Neurosci Biobehav Rev 28:273-283. CrossRef Medline

Blasco-Ibáñez JM, Martínez-Guijarro FJ, Freund TF (2000) Recurrent mossy fibers preferentially innervate parvalbumin-immunoreactive interneurons in the granule cell layer of the rat dentate gyrus. Neuroreport 11:3219-3225. CrossRef Medline

Chandramohan Y, Droste SK, Reul JM (2007) Novelty stress induces phospho-acetylation of histone $\mathrm{H} 3$ in rat dentate gyrus granule neurons through coincident signalling via the $N$-methyl-D-aspartate receptor and the glucocorticoid receptor: relevance for c-fos induction. J Neurochem 101:815-828. CrossRef Medline

Chandramohan Y, Droste SK, Arthur JS, Reul JM (2008) The forced swimming-induced behavioural immobility response involves histone $\mathrm{H} 3$ phospho-acetylation and c-Fos induction in dentate gyrus granule neurons via activation of the $N$-methyl-D-aspartate/extracellular signalregulated kinase/mitogen- and stress-activated kinase signalling pathway. Eur J Neurosci 27:2701-2713. CrossRef Medline

Clark PJ, Bhattacharya TK, Miller DS, Rhodes JS (2011) Induction of c-fos, Zif268, and Arc from acute bouts of voluntary wheel running in new and preexisting adult mouse hippocampal granule neurons. Neuroscience 184:16-27. CrossRef Medline

Clénet F, Bouyon E, Hascoët M, Bourin M (2006) Light/dark cycle manipulation influences mice behaviour in the elevated plus maze. Behav Brain Res 166:140-149. CrossRef Medline

Cornélio AM, Nunes-de-Souza RL (2007) Anxiogenic-like effects of mCPP microinfusions into the amygdala (but not dorsal or ventral hippocampus) in mice exposed to elevated plus-maze. Behav Brain Res 178:82-89. CrossRef Medline

Curtis DR, Duggan AW, Felix D, Johnston GA (1970) GABA, bicuculline and central inhibition. Nature 226:1222-1224. CrossRef Medline

de Feo MR, Mecarelli O, Ricci GF (1985) Bicuculline- and allylglycineinduced epilepsy in developing rats. Exp Neurol 90:411-421. CrossRef Medline

DeVries AC, Gerber JM, Richardson HN, Moffatt CA, Demas GE, Taymans SE, Nelson RJ (1997) Stress affects corticosteroid and immunoglobulin concentrations in male house mice (Mus musculus) and prairie voles (Microtus ochrogaster). Comp Biochem Physiol A Physiol 118:655-663. CrossRef Medline

Drazen DL, Bilu D, Edwards N, Nelson RJ (2001) Disruption of poly (ADPribose) polymerase (PARP) protects against stress-evoked immunocompromise. Mol Med 7:761-766. Medline

Duman CH, Schlesinger L, Russell DS, Duman RS (2008) Voluntary exercise produces antidepressant and anxiolytic behavioral effects in mice. Brain Res 1199:148-158. CrossRef Medline

Epp JR, Scott NA, Galea LA (2011) Strain differences in neurogenesis and activation of new neurons in the dentate gyrus in response to spatial learning. Neuroscience 172:342-354. CrossRef Medline

Fanselow MS, Dong HW (2010) Are the dorsal and ventral hippocampus functionally distinct structures? Neuron 65:7-19. CrossRef Medline

File SE, Aranko K (1988) Sodium valproate and chlordiazepoxide in the elevated plus-maze test of anxiety in the rat. Neuropsychobiology 20:82-86. CrossRef Medline

Freund RK, Marley RJ, Wehner JM (1987) Differential sensitivity to bicuculline in three inbred mouse strains. Brain Res Bull 18:657-662. CrossRef Medline

Fuss J, Ben Abdallah NM, Vogt MA, Touma C, Pacifici PG, Palme R, Witzemann V, Hellweg R, Gass P (2010a) Voluntary exercise induces anxietylike behavior in adult C57BL/6J mice correlating with hippocampal neurogenesis. Hippocampus 20:364-376. Medline

Fuss J, Ben Abdallah NM, Hensley FW, Weber KJ, Hellweg R, Gass P (2010b) Deletion of running-induced hippocampal neurogenesis by irradiation prevents development of an anxious phenotype in mice. PLoS One 5:e12769. CrossRef Medline

Ge S, Pradhan DA, Ming GL, Song H (2007) GABA sets the tempo for activitydependent adult neurogenesis. Trends Neurosci 30:1-8. CrossRef Medline

Glasper ER, Schoenfeld TJ, Gould E (2012) Adult neurogenesis: optimizing hippocampal function to suit the environment. Behav Brain Res 227:380383. CrossRef Medline

Guzowski JF, Miyashita T, Chawla MK, Sanderson J, Maes LI, Houston FP, Lipa P, McNaughton BL, Worley PF, Barnes CA (2006) Recent behavioral history modifies coupling between cell activity and Arc gene transcription in hippocampal CA1 neurons. Proc Natl Acad Sci U S A 103: 1077-1082. CrossRef Medline

Hajos N, Acsady L, Freund TF (1996) Target selectivity and neurochemical characteristics of VIP-immunoreactive interneurons in the rat dentate gyrus. Eur J Neurosci 8:1415-1431. Medline

Hayase T (2013) Working memory- and anxiety-related behavioral effects of repeated nicotine as a stressor: the role of cannabinoid receptors. BMC Neurosci 14:20. CrossRef Medline

Heldt SA, Mou L, Ressler KJ (2012) In vivo knockdown of GAD67 in the amygdala disrupts fear extinction and the anxiolytic-like effect of diazepam in mice. Transl Psychiatry 2:e181. CrossRef Medline

Herring MP, O'Connor PJ, Dishman RK (2010) The effect of exercise training on anxiety symptoms among patients: a systematic review. Arch Intern Med 170:321-331. CrossRef Medline

Hill LE, Droste SK, Nutt DJ, Linthorst AC, Reul JM (2010) Voluntary exercise alters $\mathrm{GABA}(\mathrm{A})$ receptor subunit and glutamic acid decarboxylase-67 gene expression in the rat forebrain. J Psychopharmacol 24:745-756. CrossRef Medline

Houser CR (2007) Interneurons of the dentate gyrus: an overview of cell types, terminal fields and neurochemical identity. Prog Brain Res 163: 217-232. CrossRef Medline

Jessberger S, Kempermann G (2003) Adult-born hippocampal neurons mature into activity-dependent responsiveness. Eur J Neurosci 18:2707-2712. CrossRef Medline

Jinno S, Kosaka T (2002) Immunocytochemical characterization of hippocamposeptal projecting GABAergic nonprincipal neurons in the mouse brain: a retrograde labeling study. Brain Res 945:219-231. CrossRef Medline

Kang TC, An SJ, Park SK, Hwang IK, Bae JC, Won MH (2003) Changed vesicular GABA transporter immunoreactivity in the gerbil hippocampus following spontaneous seizure and vigabatrin administration. Neurosci Lett 335:207-211. CrossRef Medline

Katano H, Masago A, Yamada K (1997) Marked alteration of c-fos and c-jun but not hsp70 messenger RNA expression in rat brain after cold-induced trauma: An in situ hybridization study. Restor Neurol Neurosci 11:153-160. Medline

Kee N, Teixeira CM, Wang AH, Frankland PW (2007) Preferential incorporation of adult-generated granule cells into spatial memory networks in the dentate gyrus. Nat Neurosci 10:355-362. CrossRef Medline

Lafrance M, Roussy G, Belleville K, Maeno H, Beaudet N, Wada K, Sarret P (2010) Involvement of NTS2 receptors in stress-induced analgesia. Neuroscience 166:639-652. CrossRef Medline

Leuner B, Gould E (2010) Structural plasticity and hippocampal function. Annu Rev Psychol 61:111-140, C1-3. CrossRef Medline

Lister RG (1987) The use of a plus-maze to measure anxiety in the mouse. Psychopharmacology 92:180-185. Medline

Luckman SM, Dyball RE, Leng G (1994) Induction of c-fos expression in hypothalamic magnocellular neurons requires synaptic activation and not simply increased spike activity. J Neurosci 14:4825-4830. Medline

Mainardi M, Landi S, Berardi N, Maffei L, Pizzorusso T (2009) Reduced responsiveness to long-term monocular deprivation of parvalbumin neurons assessed by c-fos staining in rat visual cortex. PLoS One 4:e4342. CrossRef Medline

Markwardt SJ, Dieni CV, Wadiche JI, Overstreet-Wadiche L (2011) Ivy/neurogliaform interneurons coordinate activity in the neurogenic niche. Nat Neurosci 14:1407-1409. CrossRef Medline

Motevasseli T, Rezayof A, Zarrindast MR, Nayer-Nouri T (2010) Role of ventral hippocampal NMDA receptors in anxiolytic-like effect of morphine. Physiol Behav 101:608-613. CrossRef Medline

Oladehin A, Waters RS (2001) Location and distribution of Fos protein 
expression in rat hippocampus following acute moderate aerobic exercise. Exp Brain Res 137:26-35. CrossRef Medline

O'Leary TP, Gunn RK, Brown RE (2013) What are we measuring when we test strain differences in anxiety in mice? Behav Genet 43:34-50. CrossRef Medline

Olson AK, Eadie BD, Ernst C, Christie BR (2006) Environmental enrichment and voluntary exercise massively increase neurogenesis in the adult hippocampus via dissociable pathways. Hippocampus 16:250-260. CrossRef Medline

Peng Z, Houser CR (2005) Temporal patterns of fos expression in the dentate gyrus after spontaneous seizures in a mouse model of temporal lobe epilepsy. J Neurosci 25:7210-7220. CrossRef Medline

Pritchard LM, Van Kempen TA, Zimmerberg B (2013) Behavioral effects of repeated handling differ in rats reared in social isolation and environmental enrichment. Neurosci Lett 536:47-51. CrossRef Medline

Rada P, Tucci S, Teneud L, Paez X, Perez J, Alba G, García Y, Sacchettoni S, del Corral J, Hernandez L (1999) Monitoring gamma-aminobutyric acid in human brain and plasma microdialysates using micellar electrokinetic chromatography and laser-induced fluorescence detection. J Chromatogr B Biomed Sci Appl 735:1-10. Medline

Rada P, Bocarsly ME, Barson JR, Hoebel BG, Leibowitz SF (2010) Reduced accumbens dopamine in Sprague-Dawley rats prone to overeating a fatrich diet. Physiol Behav 101:394-400. CrossRef Medline

Ramirez-Amaya V, Marrone DF, Gage FH, Worley PF, Barnes CA (2006) Integration of new neurons into functional neural networks. J Neurosci 26:12237-12241. CrossRef Medline

Redila VA, Christie BR (2006) Exercise-induced changes in dendritic structure and complexity in the adult hippocampal dentate gyrus. Neuroscience 137:1299-1307. CrossRef Medline

Rezvanfard M, Zarrindast MR, Bina P (2009) Role of ventral hippocampal GABA(A) and NMDA receptors in the anxiolytic effect of carbamazepine in rats using the elevated plus maze test. Pharmacology 84:356-366. CrossRef Medline

Salam JN, Fox JH, Detroy EM, Guignon MH, Wohl DF, Falls WA (2009) Voluntary exercise in C57 mice is anxiolytic across several measures of anxiety. Behav Brain Res 197:31-40. CrossRef Medline

Sharp FR, Sagar SM, Hicks K, Lowenstein D, Hisanaga K (1991) c-fos mRNA, Fos, and Fos-related antigen induction by hypertonic saline and stress. J Neurosci 11:2321-2331. Medline

Sik A, Penttonen M, Buzsáki G (1997) Interneurons in the hippocampal dentate gyrus: an in vivo intracellular study. Eur J Neurosci 9:573-588. CrossRef Medline

Singer BH, Gamelli AE, Fuller CL, Temme SJ, Parent JM, Murphy GG (2011) Compensatory network changes in the dentate gyrus restore long-term potentiation following ablation of neurogenesis in young-adult mice. Proc Natl Acad Sci U S A 108:5437-5442. CrossRef Medline

Skirzewski M, López W, Mosquera E, Betancourt L, Catlow B, Chiurillo M, Loureiro N, Hernández L, Rada P (2011) Enhanced GABAergic tone in the ventral pallidum: memory of unpleasant experiences? Neuroscience 196:131-146. CrossRef Medline

Snyder JS, Choe JS, Clifford MA, Jeurling SI, Hurley P, Brown A, Kamhi JF, Cameron HA (2009a) Adult-born hippocampal neurons are more numerous, faster maturing, and more involved in behavior in rats than in mice. J Neurosci 29:14484-14495. CrossRef Medline

Snyder JS, Glover LR, Sanzone KM, Kamhi JF, Cameron HA (2009b) The effects of exercise and stress on the survival and maturation of adultgenerated granule cells. Hippocampus 19:898-906. CrossRef Medline
Snyder JS, Radik R, Wojtowicz JM, Cameron HA (2009c) Anatomical gradients of adult neurogenesis and activity: young neurons in the ventral dentate gyrus are activated by water maze training. Hippocampus 19: 360-370. CrossRef Medline

Snyder JS, Soumier A, Brewer M, Pickel J, Cameron HA (2011) Adult hippocampal neurogenesis buffers stress responses and depressive behavior. Nature 476:458-461. CrossRef Medline

Snyder JS, Clifford MA, Jeurling SI, Cameron HA (2012) Complementary activation of hippocampal-cortical subregions and immature neurons following chronic training in single and multiple context versions of the water maze. Behav Brain Res 227:330-339. CrossRef Medline

Song J, Zhong C, Bonaguidi MA, Sun GJ, Hsu D, Gu Y, Meletis K, Huang ZJ, Ge S, Enikolopov G, Deisseroth K, Luscher B, Christian KM, Ming GL, Song H (2012) Neuronal circuitry mechanism regulating adult quiescent neural stem-cell fate decision. Nature 489:150-154. CrossRef Medline

Spruston N, McBain C (2007) Structural and functional properties of hippocampal neurons. In: The hippocampus book (Anderson P, Morris R, Amaral D, Bliss T, O’Keefe J, eds). New York: Oxford UP.

Stranahan AM, Khalil D, Gould E (2006) Social isolation delays the positive effects of running on adult neurogenesis. Nat Neurosci 9:526-533. CrossRef Medline

Stranahan AM, Khalil D, Gould E (2007) Running induces widespread structural alterations in the hippocampus and entorhinal cortex. Hippocampus 17:1017-1022. CrossRef Medline

Tallent MK (2007) Somatostatin in the dentate gyrus. Prog Brain Res 163: 265-284. CrossRef Medline

Tashiro A, Makino H, Gage FH (2007) Experience-specific functional modification of the dentate gyrus through adult neurogenesis: a critical period during an immature stage. J Neurosci 27:3252-3259. CrossRef Medline

Trejo JL, Llorens-Martín MV, Torres-Alemán I (2008) The effects of exercise on spatial learning and anxiety-like behavior are mediated by an IGF-I-dependent mechanism related to hippocampal neurogenesis. Mol Cell Neurosci 37:402-411. Medline

van Praag H, Kempermann G, Gage FH (1999) Running increases cell proliferation and neurogenesis in the adult mouse dentate gyrus. Nat Neurosci 2:266-270. CrossRef Medline

Vazdarjanova A, Ramirez-Amaya V, Insel N, Plummer TK, Rosi S, Chowdhury S, Mikhael D, Worley PF, Guzowski JF, Barnes CA (2006) Spatial exploration induces ARC, a plasticity-related immediate-early gene, only in calcium/calmodulin-dependent protein kinase II-positive principal excitatory and inhibitory neurons of the rat forebrain. J Comp Neurol 498: 317-329. CrossRef Medline

Walf AA, Frye CA (2007) The use of the elevated plus maze as an assay of anxiety-related behavior in rodents. Nat Protoc 2:322-328. CrossRef Medline

Zaben M, Sheward WJ, Shtaya A, Abbosh C, Harmar AJ, Pringle AK, Gray WP (2007) The neurotransmitter VIP expands the pool of symmetrically dividing postnatal dentate gyrus precursors via VPAC2 receptors or directs them toward a neuronal fate via VPAC1 receptors. Stem Cells 27:25392551. CrossRef Medline

Zheng H, Rinaman L (2013) Yohimbine anxiogenesis in the elevated plus maze requires hindbrain noradrenergic neurons that target the anterior ventrolateral bed nucleus of the stria terminalis. Eur J Neurosci. Advance online publication. Retrieved Feb. 1, 2013. doi:10.1111/ejn.12123. CrossRef Medline 